\title{
SYNTHESIS OF SOME NEW CHIRAL CROWN ETHERS AND THEIR APPLICATION TO THE EXTRACTION OF RADIOELEMENTS
}

\author{
G. Peiffer *, Ch. Siv , C. Marchi, A. Bendayan and M.El Malouli Bibout \\ Laboratoire des Organophosphores (URA 1409), Université d'Aix Marseille III, Av. Escadrille \\ Normandie-Niemen, BP 552, 13397 Marseille Cedex 13 France
}

\begin{abstract}
A series of chiral crown ethers derived from the readily accessible $\alpha$-amino acids: L-valine, L-leucine, L-isoleucine and L-phenylalanine respectively, via their hydroxyacid and diol intermediates, were synthesized and used as extractants for various radioelements: from alkaline earth metals and transition metals to lanthanide and actinide metals.
\end{abstract}

\section{Introduction:}

A central topic to host-guest chemistry is the principle of recognition which is the practical manifestation of successful receptor design (1). However, chirality was recognized as a necessary and indispensable criterion of synthetic receptor molecule design, and since molecular complexation is a precondition for receptor functions, a large number of chemists have focused their efforts on the elaboration of chiral macrocyclic ethers and their analogues as enzyme models(2). Since nature itself is a readily available source of chirality, chiral "crown like "compounds deriving from $\alpha$-amino acid precursors, became an area of rapidly expanding interest (3), and therefore, various strategies have been suggested for their synthesis to show out new original applications; examples include, racemic resolution, enantioselective synthesis and stereospecific synthesis. Although these "crown-like" compounds present interesting ionophoric properties, their complexing potential study was limited to alkali-metal cations (4). It is then surprising that so little is known about their extracting ability of heavy metals since the incorporation of chiral centers may somewhat introduce higher lipophilicity. The latter is generated by alkyl groups and in the mean time chiral centers rigidify the crown skeleton (5). These factors are known to enhance relative cation selectivities (6). Therefore, other parameters such as crown cavity size and nature of donor atoms could also influence this behaviour and hence need to be probed .

\section{Synthesis of chiral crown ethers:}

Our contribution deals with the preparation of a series of chiral crown ethers (Scheme 1) in which the dimension of the cavity from an eighteen membered ring, is taken unchanged.

The initial chiral glycols were obtained from the readily accessible $\alpha$-amino acids: L-valine, L-leucine, L-isoleucine and L-phenylalanine respectively, via their hydroxyacid intermediates by 
known methods (7). The synthesis of substituted crown ethers $4 \mathrm{a}-\mathrm{d}$ is accomplished by the condensation of the corresponding chiral glycols with pentaethylene glycol ditosylate (8), in which cyclization is performed with the aid of a template sodium ion (9). It is worth noting at this stage that the optical rotating power of our chiral precursors is not negligible but vanishes after cyclization despite the fact that the configurations around the asymmetric carbons are not affected. The results of the synthesis are listed in the experimental section.
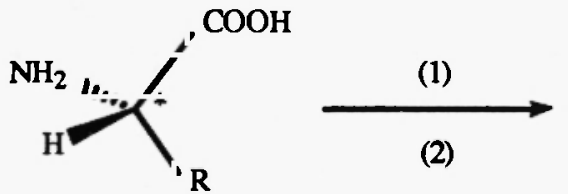

(2)
(a) : $\mathrm{R}=\cdot \mathrm{CH}\left(\mathrm{CH}_{3}\right)_{2}, \mathrm{~L}-\mathrm{Valine}$
(b) : $\mathrm{R}=-\mathrm{CH}_{2} \mathrm{CH}\left(\mathrm{CH}_{3}\right)_{2}$, L-Leucine
(d) : $\mathrm{R}=-\mathrm{CH}_{2} \mathrm{~Pb}$, L-Phenylalanine
(1) : $\mathrm{NaNO}_{2} / \mathrm{CH}_{3} \mathrm{COOH}$
(2) : $\mathrm{LAAlH}_{4} /$ T.H.F.
(3) : $\mathrm{NaOH} /$ Dioxane $/ \mathrm{H}_{2} \mathrm{O}$

(c) : $\mathrm{R}=-\mathrm{CH}\left(\mathrm{CH}_{3}\right) \mathrm{CH}_{2} \mathrm{CH}_{3}$, L-Isoleucine

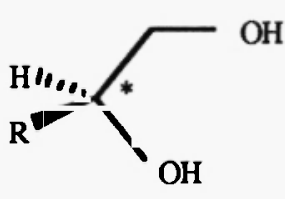

3ad

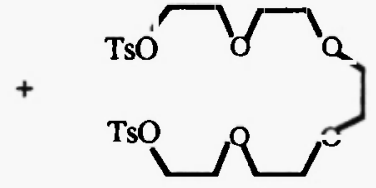

(3)

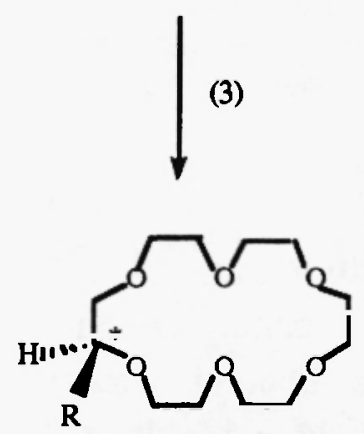

4a-d

Scheme 1

\section{Radioelements extraction:}

The second part of this contribution concerns the use of these macrocycles to extract some radioelements. The principle is based on the well known liquid-liquid extraction process in which chemical interactions are exhibited. To this end, we have studied two types of extractions: first, the metal cation is uptaken from a radioactive aqueous phase by the extractant in an organic one; secondly, the latter is extracted by a new aqueous phase exempt from radioelements but containing sodium citrate, so as to study the ability of our compounds to extract and release radioelements (reextraction). In both cases, the same procedure is used: equal volumes of organic solvent containing the extractant [L]o and aqueous solution containing the mineral radioelement $\left[\mathrm{Mm}^{\mathrm{m}}\right]_{\mathrm{a}}$ are shaken until the distribution equilibrium of the cations between the two phases is achieved:

$$
\left[\mathrm{M}^{\mathrm{m}+}\right]_{\mathrm{a}}+\mathrm{m}[\mathrm{A}]_{\mathrm{a}}+\mathrm{n}[\mathrm{L}]_{0}====\left[\mathrm{MLn} \mathrm{A}_{\mathrm{m}}\right] \mathrm{o}
$$


The two phases are centrifuged and both are analysed for the cations $\left[\mathrm{Mm}^{+}\right] \mathrm{a}$ or the complexes [ $M L_{n} A_{m}$ ]o. The distribution coefficient $D$ was measured as the ratio of the radioactivity between the two phases:

$$
D=\frac{\left[M L_{n} A_{m}\right]_{0}}{\left[M^{m+}\right]_{a}}
$$

In the present work, two series of radioelements were tested: the first group belonging to the actinides ( $\alpha$-emitting elements) as: Pu 231, Np 237 and Am 241; the results are listed in table 1, and the second from alkaline earth, transition and lanthanides ( $\gamma$ - emitting elements) of which: Mn 54, Co 60, Sr 85, Cs 137 and Eu 152, are the main ones.

In the case of $\alpha$-emitting actinides (table1), results are interesting in that distribution coefficient values are much higher. As seen, americium is not extracted. This was expected since tested crown ethers usually failed and the reason is not yet well understood; the most commonly used extractant is a C.M.P.O derivative e.g. (N,N-diisopropyl) octyl phenyl carbamoylmethylphosphine oxide, with which the $D$ values obtained are closer to unit $(D=1.2$ in NPHE Nitro Phenyl Hexyl Ether)(10).

It emerges also from our results that in addition to the ligand lipophilicity, chirality is also an important factor in the extraction process. The preferential extraction of plutonium and neptunium is illustrated on the basis of the following sequence: $4 \varepsilon>\underline{40}>\underline{4 d}>\underline{4 a}$; in which $4 \mathrm{c}$ originates from isoleucine, the only two chiral aminoacid centers under consideration.

Table 1. Evolution of the distribution coefficient ( $D$ ) of the radioisotopes as a measure of radioactivity ratios in both phases during extraction;

\begin{tabular}{ccccc}
\hline Compound & Phases radioactivity ratios & \multicolumn{3}{c}{ ( $\alpha$-Radioelements $)$} \\
\hline & $\left(\mathrm{D}=\mathrm{P}_{\mathrm{o}} / \mathrm{R}_{\mathrm{a}}\right)$ & Pu231 & No 237 & Am 241 \\
\hline 4a & $\mathrm{D}$ & 0.019 & 0.085 & 0.004 \\
& $(\mathrm{De})$ & 0.414 & 0.103 & \\
\hline 4b & $\mathrm{D}$ & 0.321 & 0.542 & 0.004 \\
& $(\mathrm{De})$ & 0.115 & 0.058 & \\
\hline 4c & $\mathrm{D}$ & 0.665 & 0.561 & 0.004 \\
& $(\mathrm{De})$ & 0.092 & 0.045 & \\
\hline 4d & $\mathrm{D}$ & 0.196 & 0.196 & 0.004 \\
& $(\mathrm{De})$ & 0.243 & 0.120 & \\
\hline
\end{tabular}

Indexes " $O$ and $a$ " refer to organic and aqueous phases respectively.

$(\mathrm{De})$ : measured radioactivity distribution after reextraction of the oraanic phase.

However, the solvent nature is probably a more crucial criterion since the complex solvation and the ligand solubility could appreciably affect metal repartition between the two phases. This 
purpose has been widely clarified by R.Frazier(11), who has shown in particular that lanthanides extraction by 18-crown- 6 and trichloroacetic acid in different solvents agrees with suggestion that for large ions, the extraction correlates with the solvent polarizability index.

However, in the case of the second series, the distribution coefficient values recorded are unfortunately too small to permit any comparison within the families selected. Indeed, they are whithin the range $10^{-2}$ to $10^{-4}$. Values of this magnitude are generally considered less significant in terms of extraction. It is then worth mentionning at this stage that chirality deriving from isoleucine may also somewhat affect the extracting power of our macrocycles; this is also evidenced by compound $\mathbf{4} \mathbf{c}$. Among crown ether analogues tested for cesium recovering, the best results were reached by using the " $21-c r o w n-7$ " ligand ( $D=1$ in nitrophenylhexylether : NPHE ) (10), while dicyclohexyl -18-crown-6 which is more lipophilic but lacking any chirality, exhibits less strontium extracting properties (12) under our conditions ( $D=4.5^{-10^{-4}}$ ). The best cesium extracting agents known to date are probably the so-called "calixarenes" (13) where higher distribution coefficients are reached. In the case of rare earth elements, separation turned out to be impossible, and indeed, many investigations to prepare efficient ion exchange resins have failed since these metals have almost the same affinity to a specific resin (14). For cobalt, manganese, europium and other lanthanides, Harrowfield and al. obtained similar results and succeeded even in preparing monocrystals of p-tert-butylcalix [8] arene and europium under basic conditions (12).

\section{Conclusion :}

Within the series of chiral crown ethers prepared $4 \mathrm{a}-\mathrm{d}$, although small (D) values were obtained in the extraction of a variety of radioelements (alkaline earth and transition metals), relatively competitive values were recorded in some cases (actinides). It seems that the extraction power of our macrocycles in the same solvent depends on at least two parameters; i.e. the fixed crown cavity size (from an eighteen membered ring) and the intrinsic chirality-lipophilicity. We have seen in particular that the second aspect is very interesting in that the presence of two chiral centers enhances both the extraction power inducing a non negligible selectivity and the ligand lipophilicity (case of $\mathbf{4} \mathbf{c}$ from isoleucine).

\section{Experimental: Typical procedures:}

Optical rotations were measured in dichloromethane at $25^{\circ} \mathrm{C}(\lambda=589 \mathrm{~nm}, \mathrm{C}=2.0)$ with a

Perkin-Elmer 241 Polarimeter. ${ }^{1} \mathrm{H}$ and ${ }^{13} \mathrm{C}$ NMR spectra were recorded with a BRUKER AC 200. Amino acids and pentaethylene glycol ditosylate were commercially available (Fluka).

1. Synthesis of Hydroxyacids: To a vigourously stirred mixture of 0.1 mole of the desired $\alpha$-amino acid and $62.5 \mathrm{ml}$ of acetic acid in $125 \mathrm{ml}$ of water, was added within 2 hours at $0^{\circ} \mathrm{C}, 15.20 \mathrm{~g}$ $(0.220$ mole) of sodium nitrite in $300 \mathrm{ml}$ of water followed by a slow addition of $5.2 \mathrm{~g}$ of sodium 
hydroxide in $75 \mathrm{ml}$ of water. After this addition, the mixture was stirred at room temperature for 12 hours before to be neutralized with $10 \mathrm{ml}$ of a $10 \mathrm{~N}$ hydrochloric acid at $0^{\circ} \mathrm{C}$. The solution was rotary evaporated and the residue is taken with $100 \mathrm{ml}$ of acetone and stirred for another $30 \mathrm{~min}$. The precipitate was suction filtered and the solvent evaporated. The residue was dissolved in $100 \mathrm{ml}$ of ether and stored at $-20^{\circ} \mathrm{C}$ during 15 hours. The suspension was then filtered and the solvent removed, to give a yellow oil that crystallizes partially giving white crystals in most cases.

\section{2-Hydroxy-3-methyl butanoic acid $\mathbf{2 a}$}

Yield $=34 \% ;$ m.p. $66^{\circ} \mathrm{C}$ (white crystals); $[\alpha]^{25} \mathrm{D}=-21.5^{\circ} .{ }^{1} \mathrm{H} \mathrm{NMR:} \mathrm{CDCl}_{3} ; \delta(p p m), \mathrm{J}(\mathrm{Hz})$ : $0.9(\mathrm{~d}, 7,3 \mathrm{H}) ; 1.05(\mathrm{~d}, 7,3 \mathrm{H}) ; 2.05-2.25(\mathrm{~m}, 1 \mathrm{H}) ; 4.15(\mathrm{~d}, 3.5,1 \mathrm{H}) ; 6.40-6.90(\mathrm{~s}, 2 \mathrm{H})$.

\section{2-Hydroxy-4-methyl pentanoic acid $2 \mathrm{~b}$}

Yield $=48 \%$; m.p. $78^{\circ} \mathrm{C}$ ( white crystals ); $[\alpha]^{25} \mathrm{D}=-26.6^{\circ} .{ }^{1} \mathrm{H} \mathrm{NMR:} \mathrm{CDCl} 3 ; \delta(p p m), J(H z)$ : $0.95(\mathrm{~d}, 6.5,6 \mathrm{H}) ; 1.60(\mathrm{t}, 6.5,2 \mathrm{H}) ; 1.80-2.00(\mathrm{~m}, 1 \mathrm{H}) ; 4.25(\mathrm{t}, 6.5,1 \mathrm{H}) ; 7.25(\mathrm{~s}, 2 \mathrm{H})$.

\section{2-Hydroxy-3-methyl pentanoic acid $2 \mathrm{c}$}

Yield = $77 \%$; b.p. $0.1 \mathrm{~mm} \mathrm{Hg}=85^{\circ} \mathrm{C}$ (Yellow oil ); $[\alpha]^{25} \mathrm{D}=-20^{\circ} .{ }^{1} \mathrm{H} \mathrm{NMR:} \mathrm{CDCl} ; \delta(\mathrm{ppm}), \mathrm{J}(\mathrm{Hz})$ : $0.90(\mathrm{t}, 7,3 \mathrm{H}) ; 1.00(\mathrm{~d}, 7,3 \mathrm{H}) ; 1.10-1.50(\mathrm{~m}, 2 \mathrm{H}) ; 1.75-2.00(\mathrm{~m}, 1 \mathrm{H}) ; 4.15(\mathrm{~d}, 3.7,1 \mathrm{H}) ; 6.45(\mathrm{~s}, 2 \mathrm{H})$.

\section{2-Hydroxy-3-phenyl propanoic acid 2d}

Yield $=48 \%$; m.p. $126^{\circ} \mathrm{C}$ (white crystals ); $[\alpha]^{25} \mathrm{D}=\cdot 46.3^{\circ} .{ }^{1} \mathrm{H} \mathrm{NMR:} \mathrm{CDCl} 3 ; \delta(\mathrm{ppm}), \mathrm{J}(\mathrm{Hz})$ : $2.98\left(\mathrm{dd}, \mathrm{J}_{1}=4, \mathrm{~J}_{2}=7,1 \mathrm{H}\right) ; 3.22\left(\mathrm{dd}, \mathrm{J}_{1}=4, \mathrm{~J}_{2}=7,1 \mathrm{H}\right) ; 4.55\left(\mathrm{dd}, \mathrm{J}_{1}=4, \mathrm{~J}_{2}=2,1 \mathrm{H}\right) ; 4.60-4.70(\mathrm{~m}, 6 \mathrm{H})$.

2. Synthesis of the corresponding diols : To a stirred suspension of $4 \mathrm{~g}(0.1 \mathrm{~mole}) \mathrm{of} \mathrm{LiAlH}_{4}$ in $100 \mathrm{ml}$ of anhydrous THF, was added at room temperature 0.1 mole of the corresponding hydroxyacid dissolved in a minimum of anhydrous THF and followed a 12 hours reflux. The mixture was left to come to ambient temperature, and the excess hydride was destroyed with an aqueous saturated solution of sodium sulphate. The precipitate is filtered and washed with ether. The organic layer was then dried over magnesium sulphate and the solvent was rotary evaporated to give an oily residue that was distilled under reduced pressure.

\section{3-Methyl butane-1,2-diol 3a}

Yield = 68\%; Yellow oil, b.p. $1 \mathrm{~mm} \mathrm{Hg}=85-90^{\circ} \mathrm{C} ;[\alpha]^{25} \mathrm{D}=17^{\circ} .{ }^{1} \mathrm{H} \mathrm{NMR:} \mathrm{CDCl} ; ; \delta(p p m), \mathrm{J}(\mathrm{Hz})$ : $0.84(\mathrm{~d}, 7,3 \mathrm{H}) ; 0.89(\mathrm{~d}, 7,3 \mathrm{H}) ; 1.50-1.65(\mathrm{~m}, 1 \mathrm{H}) ; 3.29\left(\mathrm{td}, \mathrm{J}_{1}=2, \mathrm{~J}_{2}=8,1 \mathrm{H}\right) ; 3.42(\mathrm{t}, 9,1 \mathrm{H}) ; 3.62$ (dd, $\left.\mathrm{J}_{1}=2, \mathrm{~J}_{2}=9,1 \mathrm{H}\right) ; 3.98(\mathrm{~s}, 2 \mathrm{H})$.

\section{4-Methyi pentane-1,2-diol 3b}

Yield $=70 \%$; Transparent oil , b.p.0,1 mm Hg $=75^{\circ} \mathrm{C} ;[\alpha]^{25} \mathrm{D}=-5.2^{\circ} .{ }^{1} \mathrm{H} \mathrm{NMR:} \mathrm{CDCl} 3 ; \delta(\mathrm{ppm})$, $J(H z): 0.79(d, 7,1 H) ; 0.82(d, 7,1 H) ; 0.92-1.10(m, 1 H) ; 1.26-132(m, 1 H) ; 1.55-1.78(m, 1 H)$; $3.25\left(\mathrm{dd}, \mathrm{J}_{1}=8, \mathrm{~J}_{2}=11.4,1 \mathrm{H}\right) ; 3.44\left(\mathrm{dd}, \mathrm{J}_{1}=2.6, \mathrm{~J}_{2}=11.4,1 \mathrm{H}\right) ; 3.54-3.68(\mathrm{~m}, 1 \mathrm{H}) ; 4.48(\mathrm{~s}, 2 \mathrm{H})$. 
3-Methyl pentane-1,2-diol 3c

Yield = 56\%; Yellow oil, b.p.0.2 mm Hg $=90^{\circ} \mathrm{C} ;[\alpha]^{25} \mathrm{D}=-1.9^{\circ} .{ }^{1} \mathrm{H} \mathrm{NMR:} \mathrm{CDCl} 3 ; \delta(p p m), J(\mathrm{~Hz})$ : $0.80(\mathrm{~d}, 7,3 \mathrm{H}) ; 0.85(\mathrm{t}, 7,3 \mathrm{H}) ; 1.00-1.22(\mathrm{~m}, 1 \mathrm{H}) ; 1.30-1.65(\mathrm{~m}, 2 \mathrm{H}) ; 3.38(\mathrm{~d}, 7.4,2 \mathrm{H}) ; 3.48(\mathrm{~d}, 7.4,2 \mathrm{H}) ;$ $3.64(q, 7.4,1 \mathrm{H}) ; 4.48(\mathrm{~s}, 2 \mathrm{H})$.

\section{3-Phenyl propane-1,2-diol 3d}

Yield $=73 \%$; White Solid, m.p. $<50^{\circ} \mathrm{C} ;[\alpha]^{25} \mathrm{D}=-123.6^{\circ} .{ }^{1} \mathrm{H} \mathrm{NMR:} \mathrm{CDCl}_{3} ; \delta(\mathrm{ppm}), \mathrm{J}(\mathrm{Hz})$ : $2.58(\mathrm{~d}, 7,2 \mathrm{H}) ; 3.30\left(\mathrm{dd}, \mathrm{J}_{1}=7.2, \mathrm{~J}_{2}=11.4,1 \mathrm{H}\right) ; 3.42\left(\mathrm{dd}, \mathrm{J}_{1}=2.6, \mathrm{~J}_{2}=11.4,1 \mathrm{H}\right) ; 3.50-3.90(\mathrm{~m}, 3 \mathrm{H})$; 6.95-7.31 (m,5H).

3. Synthesis of macrocycles: To the desired chiral diol $\mathbf{3}(3.0 \mathrm{mmoles})$ dissolved in $3 \mathrm{ml}$ of dioxane, were added 6.0 mmoles of sodium hydroxide dissolved in a minimum quantity of water. The mixture was stirred for $20 \mathrm{~min}$ at room temperature. After that, one equivalent of pentaethylene glycol ditosylate in $2 \mathrm{ml}$ of dioxane was added and the mixture was refluxed under vigourous stirring for 24 hours. Following cooling to ambient temperature, filtration and solvent evaporation, the residue was taken by dichloromethane and dried over magnesium sulphate. The oily residue obtained in each case was purified by liquid chomatography over silica gel using the solvent system: Ethyl acetate / Hexane (70/30).

\section{2-Isopropyl-1,3,6,9,12,15-pentaoxacyclooctadecane $4 \mathrm{a}$.}

Yield = 33\%; Yellow oil; $[\alpha]^{25} \mathrm{D}=0.8^{\circ} .{ }^{1} \mathrm{H} \quad \mathrm{NMR}: \mathrm{CDCl}_{3} ; \delta(\mathrm{ppm}), \mathrm{J}(\mathrm{Hz}): 0.86(\mathrm{~d}, 7,3 \mathrm{H})$; $0.89(\mathrm{~d}, 7,3 \mathrm{H}) ; 1.58-1.75(\mathrm{~m}, 1 \mathrm{H}) ; 3.52-3.63(\mathrm{~m}, 22 \mathrm{H}) ; 4.08(\mathrm{t}, 4.8,1 \mathrm{H}) ; 7.21-7.74(\mathrm{~m}, 4 \mathrm{H})$. ${ }^{13} \mathrm{C} \mathrm{NMR:} \mathrm{CDCl}_{3} ; \delta$ (ppm ): $11.25\left(\mathrm{CH}_{3}\right) ; 14.69\left(\mathrm{CH}_{3}\right) ; 36.54(\mathrm{CH}) ; 64.71(\mathrm{CH}) ; 68.73-77.74$ (CH2).

\section{2-Isobutyl-1,3,6,9,12,15-hexaoxacyclooctadecane 4 b}

Yield $=45 \%$; Orange oil; $[\alpha]^{25} \mathrm{D}=0.6^{\circ} .{ }^{1} \mathrm{H}$ NMR: $\mathrm{CDCl}_{3} ; \delta(\mathrm{ppm})$, J (Hz): $0.84(2 \mathrm{~d}, 6.5,6 \mathrm{H})$; 1.22-1.46 (m,2H ); 1.59-1.87 (m,1H); 3.51-3.90 (m,22H ). ${ }^{13} \mathrm{C} \mathrm{NMR:} \mathrm{CDCl}_{3} ; \delta(\mathrm{ppm}): 22.07\left(\mathrm{CH}_{3}\right)$; $24.43\left(\mathrm{CH}_{3}\right) ; 40.27(\mathrm{CH}) ; 42.00\left(\mathrm{CH}_{2}\right) ; 68.33(\mathrm{CH}) ; 68.64-77.75\left(\mathrm{CH}_{2}\right)$.

\section{2-(1-inethyl)propyl-1,3,6,9,12,15-hexaoxacyclooctadecane $4 \underline{c}$}

Yield $=28 \%$; Yellow oil; $[\alpha]^{25} \mathrm{D}=-0.5^{\circ} .{ }^{1} \mathrm{H} \quad \mathrm{NMR}: \mathrm{CDCl}_{3} ; \delta(\mathrm{ppm}), \mathrm{J}(\mathrm{Hz}): 0.78(\mathrm{~d}, 7,3 \mathrm{H}) ; 0.82$ $(\mathrm{t}, 7,3 \mathrm{H}) ; 1.11-1.18(\mathrm{~m}, 1 \mathrm{H}) ; 1.44-1.51(\mathrm{~m}, 2 \mathrm{H}) ; 3.52-3.66(\mathrm{~m}, 22 \mathrm{H}) ; 4.08(\mathrm{t}, 3,1 \mathrm{H}) .{ }^{13} \mathrm{C} \mathrm{NMR:} \mathrm{CDCl}_{3}$; $\delta$ (ppm): $18.17\left(\mathrm{CH}_{3}\right) ; 18.69\left(\mathrm{CH}_{3}\right) ; 30.92(\mathrm{CH}) ; 67.08\left(\mathrm{CH}_{2}\right) ; 64.88(\mathrm{CH}) ; 68.69-77.72(\mathrm{CH} 2)$.

\section{2-Benzyl-1,3,6,9,12,15-hexaoxacyclooctadecane $\underline{4 d}$}

Yield $=31 \%$; Yellow oil; $[\alpha]^{25} \mathrm{D}=-10.5^{\circ},{ }^{1} \mathrm{H}$ NMR: $\mathrm{CDCl}_{3} ; \delta(\mathrm{ppm}), \mathrm{J}(\mathrm{Hz}): 2.41(\mathrm{~s}, 3 \mathrm{H}) ; 2.71$ $(\mathrm{d}, 7,2 \mathrm{H}) ; 3.56-3.67(\mathrm{~m}, 22 \mathrm{H}) ; 4.12(\mathrm{t}, 4.8,1 \mathrm{H}) ; 7.17-7.29(\mathrm{~m}, 5 \mathrm{H}) .13 \mathrm{C} \mathrm{NMR:} \mathrm{CDCl} 3 ; \delta(\mathrm{ppm}): 39.88$ $\left(\mathrm{CH}_{2} \mathrm{Ph}\right) ; 66.04(\mathrm{CH}) ; 66.72-77.72(\mathrm{CH} 2) ; 126.12-133.17$ (C arom). 
4. Extraction procedure : $3 \mathrm{ml}$ of the organic phase consisting of 0.01 mole of the desired macrocycle 4 in nitrophenylhexylether (NPHE), and $3 \mathrm{ml}$ of the aqueous phase (as indicated below), were shaken for $30 \mathrm{~min}$, followed phases separation and radioactivity counting in both of them.

For the $\gamma$-emitting series, aqueous solution was prepared as follows:

Mn 54 (700 KBq/l); Co 60 (430 KBq/); Sr 85 (730 KBq/l); Cs 137 (1320 KBq/l); Eu 152 (1100 KBq//)). Radioactivity counting was made on a $2 \mathrm{ml}$ solution .

For the $\alpha$ - emitting series, aqueous solutions were prepared as follows:

Pu 231 (14648 impacts/min); ivr 237 (14027 impacts/min); Am 241 (14648 impacts/min).

Radioactivity counting was made by liquid scintillation. Reextraction experiments were performed in the same conditisns, from $2 \mathrm{ml}$ of the organic phase and $2 \mathrm{ml}$ of a 0.25 mole/l citrate aqueous phase .

Acknowledgments : This work was partly achieved at the C.E.A. (Commissariat à l'Energie Atomique, Service des effluents et dechets de faible et moyenne radioactivite; Cadarache-France). From which, we warmly thank Dr. J.F. Dozol for helpful discussions and materials supplyed.

\section{References}

(1) R.M. Izatt, C.Y. Zhu, P. Huszthy and J.S. Bradshaw. Enantiomeric Recognition in MacrocyclePrimary Ammonium cation systems in crown ethers: Toward Future Applications; Cooper,S.R., Ed.,VCH Press: New York, 1992

(2) Y. Chao, G.R. Weisman, C.D.Y. Sogah and D.J. Cram, J.Am.Chem.Soc 101, 4948 (1979); J. Crosby, M.E. Fakley, C. Gemmel, K. Martin, A. Quick, A.M.Z. Slawin, H. Shahriari-Zavareh, J. Fraser-Stoddart and D.J. Williams, Tetrahedron Lett. 30,3849 (1989); D.A. Laidler and J.F. Stoddart, J. Chem. Soc. Chem. Commun. 23, 979 (1976)

(3) P. Hutszthy, J.S. Bradshaw, C.Y. Zhu, R.M. Izatt and S. Lifson, J. Org. Chem . 56, 3330 (1991); Dunnill P., Wiseman A., Blakebrough N., " Enzymic and non-enzymic catalysis ", Ed. Ellis Horwood Ltd, Chichester, 1980; M. Zinic and V. Skaric, J.Org.Chem . 53, 2582 (1988); J.S. Bradshaw, P. Hutszthy, C.W. McDaniel, C.Y. Zhu, N.K. Dalley, R.M. Izatt and S. Lifson, J.Org.Chem . 55, 3129 (1990); Y. Li, L. Echegoyen, M.V. Martinez-Diaz, J. Mendoza and T. Torres, J.Org.Chem. 56, 4193 (1991)

(4) T.W. Bell, G.M. Lein, H. Nakamura and D.J. Cram,J.Org.Chem . 48, 4728 (1983); E. Blasius, R.A. Raussch, G.D. Andreetti and J. Rebisant, Chem . Ber . 117, 1113 (1984)

(5) K. Nakagawa, S. Okada, Y. Inoue, A. Tai and T. Hakushi, Anal.Chem . 60, 2527 (1988)

(6) K. Nakagawa, Y. Inoue and T. Hakushi, J.Chem .Research (S) . 348, (1990)

(7) A . Focella, F. Bizzarro and C. Exon, Synth . Commun . 21, 2165 (1991)

(8) E.V. Dehmlow and V. Knufinke, Liebigs Ann .Chem . 1091 (1991); F.L. Cook, T.C. Camso, M.P. Byrne, C.W. Bowers, D.H. Sepck and C.L. Liotta, Tetrahedron Lett. 46, 4029 (1974) 
(9) R.N. Greene, Tetrahedron Lett. 18, 1793 (1992)

(10) Report from the Commissariat à L'Energie Atomique : unpublished results

(11) R. Frazier, J.Rad.Nucl.Chem .1, 63 (1992)

(12) J.M. Harrowfield, M.I. Hogden, A.H. White and F.R. Wilner, Austral .J.Chem . 42, 949 (1989)

(13) R. Izatt, J. Christensen and R. Hawkins, U.S.Patent 4,477,377. 16 Oct 1984

(14) H. Dugas, Bioorganic Chemistry: A Chemical Approach to Enzyme Action. 2nd Ed, SpringerVerlag, New York, N.Y., 1989

Received December 3, 1994 